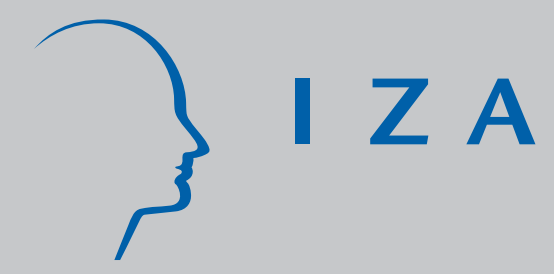

IZA DP No. 2722

Cohort-Level Sex Ratio Effects on Women's Labor Force Participation

Shoshana Grossbard

Catalina Amuedo-Dorantes

April 2007 


\title{
Cohort-Level Sex Ratio Effects on Women's Labor Force Participation
}

\author{
Shoshana Grossbard \\ San Diego State University \\ and IZA \\ Catalina Amuedo-Dorantes \\ San Diego State University \\ and IZA
}

Discussion Paper No. 2722

April 2007

IZA
P.O. Box 7240
53072 Bonn
Germany

Phone: +49-228-3894-0

Fax: +49-228-3894-180

E-mail: iza@iza.org

Any opinions expressed here are those of the author(s) and not those of the institute. Research disseminated by IZA may include views on policy, but the institute itself takes no institutional policy positions.

The Institute for the Study of Labor (IZA) in Bonn is a local and virtual international research center and a place of communication between science, politics and business. IZA is an independent nonprofit company supported by Deutsche Post World Net. The center is associated with the University of Bonn and offers a stimulating research environment through its research networks, research support, and visitors and doctoral programs. IZA engages in (i) original and internationally competitive research in all fields of labor economics, (ii) development of policy concepts, and (iii) dissemination of research results and concepts to the interested public.

IZA Discussion Papers often represent preliminary work and are circulated to encourage discussion. Citation of such a paper should account for its provisional character. A revised version may be available directly from the author. 


\section{ABSTRACT \\ Cohort-Level Sex Ratio Effects on Women's Labor Force Participation*}

It follows from a number of theoretical models of marriage that the scarcer women are relative to men, i.e. the higher the sex ratio, the less married women are likely to participate in the labor force. Such sex ratio effects may be stronger among less educated women. These predictions are tested using individual data from Current Population Surveys for four regions of the U.S. (Northeast, Midwest, South and West), and for the U.S. as a whole, covering the period 1965 to 2005 at five-year intervals. Within-region sex ratio variation results from variation in cohort size (due principally to large fluctuations in number of births) and limited fluctuations in the difference between male and female age at marriage. As hypothesized, we find that sex ratios are inversely related to women's labor force participation, reflecting that ceteris paribus women born in years of peak baby-boom are more likely to be in the labor force than women born in years of peak baby-bust. Additionally, weaker sex ratio effects are found among educated women in two of the four regions of the United States.

JEL Classification: J1, J2

Keywords: female labor force participation, sex ratios, cohorts, education, marriage markets

Corresponding author:

Shoshana Grossbard

Department of Economics

San Diego State University

San Diego, CA 92182-4485

USA

E-mail: shosh@mail.sdsu.edu

\footnotetext{
${ }^{*}$ We are very grateful to the following for helpful comments: two anonymous referees, Olivia EkertJaffe, Clive Granger, Michael Grossman, David Neumark, Sol Polachek, William Rodgers, and participants at workshops at the College of William and Mary, CUNY Graduate Center, NYU, and Princeton University.
} 


\section{Introduction}

Women's labor force participation (LFP) rates in the U.S. experienced a marked increase between 1965 and 1980, the improvement being most remarkable for married women. For instance, during these fifteen years, the LFP rate of married women ages 25 to 29 rose from 33 percent to 58 percent in the labor force, an increase of 25 percentage points. In contrast, in the next fifteen years — from 1980 to 1995 — the LFP rate for this age group grew by only 11 percentage points, to 69 percent of the labor force. Furthermore, between 1995 and 2005, the LFP rate of married women ages 25 to 29 decreased slightly to 66.5 percent. Likewise, during the same ten years, the LFP of married women ages 30 to 34 decreased by 2.5 percentage points.

Economic explanations of such historical trends in female labor supply have principally focused on the effects of wages, income, educational attainment, and the number of children born to potential labor force participants. In this paper, we argue that historical fluctuations in cohort size, due principally to the changing number of births in adjacent cohorts, cause fluctuations in sex ratios- the ratio of men to women--that affect marriage market conditions. We predict that such fluctuations in sex ratio help explain female LFP rates. Additionally, we predict that sex ratio effects (regional and at the cohort level) will be stronger among women with less education. Both predictions, consistent with both Demand and Supply and collective economic theories of marriage, are tested using individual data from Current Population Surveys for the U.S. as a whole and for each of its four regions (Northeast, Midwest, South and West) covering the 1965-2005 period at five-year intervals.

Our analysis expands on previous analyses of changes in women's LFP over time by Pencavel (1998) and Grossbard-Shechtman and Granger (1998) that are also based on the analysis of Current Population Survey (CPS) data. Pencavel (1998) documented considerable 
variation in women's LFP rates across cohorts and the limited explanatory power of fluctuations in wage and income -both variables typically included in economic models of labor supply. Using time-series aggregated CPS data for the period 1965 to 1990, Grossbard-Shechtman and Granger (1998) showed that the women experiencing the most rapid increases in LFP had been born in a growing cohort, i.e. a baby-boom. ${ }^{1}$ Using aggregate CPS data, and similar aggregate data for Japan, Fukuda (2006) utilizes an innovative Bayesian cohort model that allows simultaneous estimation of age, period, and cohort effects on female labor force participation. While cohort effects in both countries were substantial--exceeding the size of period effects in their magnitude—-the U.S. had larger cohort effects on female LFP than Japan.

We add to these studies by including cohort-level sex ratios in our analysis, by allowing for regional variation, and by expanding the time span of the analysis to 2005. Additionally, we examine how sex ratio effects on women's LFP rates differ by educational attainment. Finally, we carry out the analysis for both married women and for all women regardless of marital status to address variations in the sex ratio effects according to women's marital status.

\section{Predictions}

\section{A) Sex Ratios}

It follows from at least three economic theories of marriage that sex ratios of marriage eligibles will be inversely related to married women’s LFP: Grossbard's demand and supply (D\&S) model of marriage (Grossbard-Shechtman’s 1984, 1993), and collective models by Chiappori $(1988,1992)$ and Rapoport, Sofer and Solaz (2006). That collective models and D\&S models lead to similar predictions is not surprising given that the second step in these two-step decision-making models are very similar. In both kinds of models, Step 2 consists of individuals

\footnotetext{
${ }^{1}$ Earlier, Heer and Grossbard-Shechtman (1981) had documented the large increase in LFP among female babyboomers and explained it in terms of the low sex ratios characterizing that generation.
} 
deciding on their labor force participation by maximizing their own utility subject to a budget constraint that includes pre-determined access to the spouse's income. In both kinds of models, access to the spouse's income is determined in Step 1 in some form of agreement between the spouses, and the agreement is likely to favor more those spouses who benefit from advantageous marriage market conditions such as high sex ratios (high ratios of male to female).

Step 1 is based on different assumptions in collective models and D\&S models. In collective models, access to the spouse's income is determined by a sharing rule agreed upon by the couple. This sharing rule may not depend on work in household production, as is the case in Chiappori (1988) and the Chiappori model predicting sex ratio effects on female LFP (Chiappori, Fortin, and Lacroix 2002), or it may depend on work in household production, as in Chiappori (1997) and Rapoport, Sofer and Solaz (2006). In Grossbard's D\&S model, work in household production plays a central role and a couple agrees on the terms of trade between work in household production and access to income (interpreted as a quasi-wage). Individuals have a supply of marital household labor, which implies that they set apart time resources that they are not willing to allocate towards any household production performed in couple, given possible levels of quasi-wage. ${ }^{2}$ Likewise, individual demands for such work involves a separation between what one is willing to purchase at different prices, and what is not demanded.

Collective models and D\&S models differ in the role marriage markets play in influencing individual bargaining. In collective models, there are no market level prices for work in household production that influence individual bargaining agreements, in a manner analogous to the role of market wages in bargaining between employer and worker. Marriage market conditions influence individual bargaining power but not market-level terms of trade between

\footnotetext{
${ }^{2}$ The separation between time one is willing to supply and time that remains devoted to self is reminiscent of a similar separation found in Lundberg and Pollak’s (1993) “Separate Spheres” model.
} 
work and access to income. In D\&S models, when marriage partners agree that one is willing to supply what the other is willing to demand at a given quasi-wage, they are influenced by the terms of trade established in informal collective bargaining between many men and women interacting in the same marriage markets. Quasi-wage earners are typically the primary workers in household production, while their spouses are typically the primary market wage earners. To the extent that there is a traditional division of labor by gender, as assumed in Becker (1973, 1981), men are likely to pay women quasi-wages.

It follows from both kinds of models that marriage market conditions influence the individual's decision on how to allocate her/his own time to work in the labor force. When marriage markets are more favorable to women, women's quasi-wages are higher (according to Step 1 in a D\&S model) and the sharing rule favors women more (according to Step 1 in a collective model). In both kinds of models, more favorable marriage market conditions for women translate into more material resources for women (in Step 1) and, consequently, as a result of an income effect, women are less likely to participate in the labor force (in Step 2). ${ }^{3}$

One advantage of the D\&S models is that they are reminiscent of labor market models and ideas can be imported from labor market analysis to the analysis of marriage markets. For example, one can look at education as a factor that influences the aggregate demand for work in marital production by women or men of different educational levels. Likewise, education can affect aggregate supply of such work. As a result, education may affect market levels of quasiwage and therefore individual opportunities for intra-household bargaining. According to Grossbard (1984, 1993), in Step 1, more educated people may be more likely to seek nonmaterial quasi-wages for work in marital household production, leading to a smaller income

\footnotetext{
${ }^{3}$ Many more of the same conclusions follow from both categories of models, including the prediction that married men will work more in the labor force if the sharing rule/quasi-wages are more in favor of women.
} 
effect in Step 2. It is also possible that more educated women may have more egalitarian marriages in which work in marital household production is more frequently replaced by contracts to outsiders, such as restaurants and child care workers. This would lead to lower material compensation for household production in Step 1 and a smaller income effect in Step 2. For both of these reasons, we predict a smaller correlation between marriage market conditions and women's labor force participation among college-educated couples than among less educated couples (see Grossbard-Shechtman and Neuman 1988). However, it is also possible that education raises productivity in work in household production and that when sex ratios increase educated women's quasi-wages, established in markets for more educated women’s work in marital production, benefit more than is the case with the quasi-wages of less educated women.

According to both models, it is also possible for the sex ratio effects on women's LFP to vary with male income and education. Marriage market conditions may not simply be a matter of how many men per woman are available in a given marriage market, but also of the extent to which these men are willing to let women obtain access to their income. A higher sex ratio is more likely to induce women's withdrawal from the labor force if men have a more attractive financial position (on the importance of sex ratios incorporating men's earning power see Lichter et al. 1995). It thus follows that there will be more of a negative correlation between married women's LFP and sex ratios at higher levels of male education and income.

Sex ratio effects on women's LFP are also expected to vary according to their marital status. On the one hand, married women's access to men's income (Step 1) is likely to vary more with marriage market conditions (as measured by sex ratios) than that of women of any other marital status (single, cohabiting, separated, widowed or divorced). Accordingly, we 
expect stronger sex ratio effects on the LFP of married women than on the LFP of women of any marital status. On the other hand, the LFP of women of any marital status -married and unmarried-is expected to vary with the sex ratio more than that of married women for two reasons. First, sex ratio effects are likely to have an effect on marital status, the higher the sex ratio, the more women are likely to be married and married women work less in the labor force. Secondly, male willingness to give women access to their income will vary with their marital status. As such, analyses of the LFP of married women are more likely to provide evidence supporting the arguments found in D\&S and collective models of marriage.

In the past, cross-city comparisons have provided evidence of a negative association between sex ratios and married women's labor supply. It has been found that married women are more likely to supply labor in cities where sex ratios are higher than average (GrossbardShechtman and Neideffer 1997, Chiappori, Fortin and Lacroix 2002, Rapoport, Sofer, and Solaz 2006). However, a negative association between regional sex ratios and women's LFP is not necessarily caused by marriage market effects on LFP (income effects due to variation in quasiwages or sharing rule). Good labor demand conditions for women may simultaneously lead women to participate more in the labor force and attract female migrants, thereby lowering sex ratios. This alternative explanation for a negative association between sex ratios and women's LFP only applies where labor migration is feasible. However, migration cannot occur across different birth cohorts and, therefore, evidence of sex ratio effects based on cohort comparisons is potentially more supportive of a marriage market theory of labor supply than evidence based on cross-regional or cross-city comparisons.

Sex ratios vary over time because of fluctuations in cohort size. Cohort size variations can cause fluctuations in sex ratio because, on average, men dating or marrying a particular 
group of women tend to be older than they are. For instance, if a particular cohort is larger than a preceding cohort, the sex ratio calculated for that particular group of women will be less than one. ${ }^{4}$ Such is the case of cohorts of women born at the beginning of a baby boom and likely to marry men born prior to that baby boom who belong to smaller cohorts. Vice-versa, if a particular cohort of women is smaller than a preceding cohort, the sex ratio will be larger than one. For example, cohorts of women born at the beginning of a baby bust will typically marry men born prior to that baby bust who belong to larger cohorts.

Table 1 indicates substantial variation in this kind of sex ratio in the U.S.A. over the period 1965-2005 when we assume a difference of two years of age between men and women at marriage -an assumption in line with the overall evolution of that age difference. It follows from that table that women born during a baby boom (baby-boomers) would be more likely to participate in the labor force than baby-busters (Heer and Grossbard-Shechtman 1981, Guttentag and Secord 1983, Grossbard-Shechtman and Granger 1998). This explains, for instance, why in the U.S. there was rapid growth in the LFP of married women ages 25 to 29 in the years 19651980. These are precisely the years during which baby-boomers were reaching these ages. In contrast, married women entering ages 25 to 29 in the period 1980-95 were born during the baby-bust. Not surprisingly, relative to their baby-boom counterparts (such as the cohort born in 1946 that reached age 25 in 1971), these baby-bust women (such as the cohort born in 1964 that reached age 25 in 1989) have experienced a substantially slower growth in participation in the labor force.

Easterlin (1980) offers an alternative explanation for the inverse relationship between the LFP of women and fluctuations in cohort size: growing cohorts, such as baby-boomers, face

\footnotetext{
${ }^{4}$ Note that the more rigid age preferences, the more fluctuations in cohort size will cause marriage market imbalances.
} 
worse income opportunities than the ones encountered by their parents when they were growing up. Baby-boom women thus may meet baby-boom men with relatively low incomes. This would also push married women into the labor force. Furthermore, according to Easterlin, babyboom couples are also expected to have fewer children, which would also support the prediction that married baby-boom women have higher LFP rates. However, if sex ratio effects on married women's LFP persist after appropriately accounting for household income and fertility, this alternative explanation can be ruled out.

\section{B) Other Variables Affecting Female Labor Force Participation}

We also build on past research on women's LFP rates and include the following variables in our analyses.

\section{Household Income and Female Wages: $\quad$ According to Mincer (1962), higher wages} had been a major reason why women were attracted to join the labor force prior to 1960 . Mincer solved a puzzle that had confounded labor economists at the time: time series results showed that women's LFP and wages were growing in the same direction, in apparent contradiction to findings of a negative association between wages and women's LFP based on cross-sectional data. Mincer resolved this puzzle by separating the effects of male and female wages. What explained women's entry into the labor force in time series were increases in women's wages, whereas increases in male wages accounted for the negative association between wages and women's LFP in cross-sections studies. Mincer interpreted the effect of married women's own wages on their LFP rates as a substitution effect and the effect of husbands' wages primarily as an income effect.

While this wage/income explanation has held for earlier periods, its effectiveness in explaining recent trends in LFP seems limited. A number of studies have indicated that, in 
recent years, women's wages and their LFP have not been moving in the same direction. Rosen (1992) pointed out that the LFP rates of women increased greatly during the 1970's, when women's wages were stagnant or declining. It is possible that a low positive association between female wages and female labor supply reflects the fact that women entering the labor market for the first time had low levels of human capital.

Based on cross-sections from various years of the CPS, Leibowitz and Klerman (1995) found that, relative to women's wages, men's wages and unemployment explained more changes in married mothers’ employment between 1971 and 1990. A possible explanation for the stronger effect exhibited by male wages on women's LFP relative to female wages is that female wages are endogenous in a study of female LFP. For any given demand for female labor, changes in the supply of that labor will cause fluctuations in wages. Therefore, we carry our analysis with and without controls for female non-labor income and for average wages earned by other women in the same age-education-region-year cell to assess the robustness of sex ratio effects in explaining female LFP to the inclusion of these two regressors.

Education: Previous studies have found that the rise in women's LFP was associated with increased levels of education. ${ }^{5}$ This is consistent with the view that education improves the individual's preparation for the job market, raising the opportunity cost of leisure and home production, leading to increased participation in the labor market. Additionally, educational attainment may also impact women’s LFP via its impact on marriage opportunities and on preferences. Educated couples tend to have a preference for a more egalitarian division of labor (Hersch 2003), which in turn may facilitate married women’s labor force participation. Therefore, we account for women's educational attainment and, as with female wages, we carry

\footnotetext{
${ }^{5}$ See, for example, Huet (1977), Shapiro and Shaw (1983), Smith and Ward (1984), Mincer (1985), Goldin (1990), and Leibowitz and Klerman (1995).
} 
out the analysis with and without controls for educational attainment in order to assess the robustness of our sex ratio effect estimates to the inclusion of this potentially endogenous regressor.

Fertility: $\quad$ The growth in women's LFP rates over time has also been shown to coincide with decreases in fertility. ${ }^{6}$ Causality here can go either way. Not only is it possible that lower fertility explained increases in women's labor supply, but higher LFP rates may have also lowered fertility. More generally, labor supply and fertility may also be spuriously related due to the effect of other variables on both labor supply and fertility (e.g. Deville 1977 and Lehrer and Nerlove 1986). Acknowledging the importance of women's childbearing on their LFP choices, and despite the difficulties of isolating its true impact due to endogeneity reasons, we control for women's fertility in some specifications with a dummy variable indicative of the presence of children less than three years old living in the household.

Change in attitudes: Partially as a result of the decreasing explanatory power of wage/income variables, ${ }^{7}$ scholars -especially those trained in sociology- have turned to cultural explanations focused on variables such as attitudes towards work and family. We include a time trend, region of residence dummies, and interaction terms between the time trend and the set of regional dummies to allow for differences in attitudes towards work and family across regions as well as over time.

In the next section, we examine the LFP effects of sex ratios over time (cohort size effects) and across regions while accounting for the aforementioned factors possibly influencing female LFP decisions.

\footnotetext{
${ }^{6}$ See, for example, Mincer (1962), Deville (1977), Ekert (1983), Smith and Ward (1984), Mincer (1985), Goldin (1990), Rosen (1992), and Leibowitz and Klerman (1995).

${ }^{7}$ In this regard, Pencavel (1998) posits that variation in male and female wages accounts for less than half of the observed changes in women's LFP rates over time.
} 


\section{Data and Empirical Methodology}

\section{A) Data}

With the exception of the data on sex ratios, the data used in this study are extracted from Current Population Surveys (CPS, March files) for four regions (Northeast, Midwest, South and West) covering the period 1965 to 2005 at five-year intervals. The CPS data are all individuallevel data, except for average female wage, that is calculated for each region/age group/year cell. Non-labor household income is defined as total household income minus the respondent's labor income.

Our sample includes women 25 to 44, and we create age dummies for the following age groups: 25 to 29, 30 to 34, and 35 to 39. Since women with young children at home have a higher likelihood of receiving intra-marriage transfers of income, we only consider women younger than 44 years old.

In calculating sex ratios, we assume that the male/female age difference at marriage is, on average, equal to two years. This assumption fits the data on first marriages in the U.S. for most of the period that we cover: ${ }^{8}$ in the period 1965-1995, despite a considerable rise in age at marriage, the age difference between male and female age at first marriage fluctuated between 2.2 and 2.7. ${ }^{9}$ Sex ratios are calculated from Census data for five-year age groups by dividing the number of all men two years older by the number of all women ages 20-24 or 25-29 (depending on the year), regardless of marital status, i.e. we compute:

Sex Ratio $=\left(M_{t-2}+M_{t-1}+M_{t}+M_{t+1}+M_{t+2}\right) /\left(F_{t}+F_{t+1}+F_{t+2}+F_{t+3}+F_{t+4}\right)$, where $M$ is the number of men and $F$ the number of women. We expect that people are most likely to be

\footnotetext{
${ }^{8}$ A more complete analysis would endogenize the gender difference in age at marriage, as it is also likely to vary with sex ratios.

${ }^{9}$ Since 1997 this gender difference in age at marriage has shrunk to an average of 1.7, fluctuating between 1.6 and 1.8 (www.census.gov).
} 
influenced by sex ratios when they are in their twenties and are most likely to enter a first marriage. What moves cohort-level variation in sex ratios is the difference between the number of women born in years $(t+3)$ and $(t+4)$ and the number of men born in years $(t-1)$ and $(t-2){ }^{10}$ The resulting cohort-level sex ratios are merged into the CPS data according to women's birth year and region of residence.

Sex ratios for women born between 1926 and 1980 and for men born between 1924 and 1978 for the entire country and by U.S. regions are shown in Table 1. Each five-year cohort was given a name related to historical events that occurred around their years of birth. For the U.S. as a whole (bold numbers), it can be seen that this sex ratio fluctuated dramatically from a minimum of 0.87 for the women born in the years 1946-50, right after World War II, (men born 1944-48), to a maximum of 1.07 for the women born in 1971-75 (men born 1969-1973) around the passage of Roe versus Wade, a landmark ruling that led the number of abortions to increase in the United States. ${ }^{11}$ The sex ratio for women born in 1966-70 and men born in 1964-68, the Moon generation, was also high at 1.06. It is also apparent from Table 1 that sex ratios were consistently higher in the Midwest than in other regions.

Table 1 also reports changes in LFP rates for married women of different ages, these changes being defined over the last five years. ${ }^{12}$ The table indicates a negative correlation between sex ratio and changes in married women's LFP. For example, it can be seen that, at almost every age, the Post-World War II generation women -the women with the lowest sex ratio- experienced faster growth in LFP than the other five-year cohorts of women. For

\footnotetext{
${ }^{10}$ The numbers of men and women born in years $t,(t+1)$, and $(t+2)$ are roughly equal and appear in both the numerator and the denominator.

${ }^{11}$ Links between abortion law changes and changes in fertility in the 1970s have been discussed, e.g. by Donohue and Levitt (2001) and Angrist and Evans (2002). Oreffice (2007) directly studies the association between abortion law changes and LFP.

${ }^{12}$ A similar table for women of all marital states is available from the authors upon request.
} 
example, on average, married women age 30-34 experienced an increase of 13.5 percentage points in LFP between 1975 and 1980, corresponding to the entry of the women of the PostWorld War II generation (born in 1946-50) into this age group. In contrast, between 1995 and 2005, women of the baby-bust cohorts (the Moon and Roe generations characterized by unusually high sex ratios) entered this age group and the LFP of married women declined by 3.6 percentage points: from 73 percent to 69.4 percent. $^{13}$

We analyze sex ratio effects on the LFP of two samples of women: (1) about 200,000 women of varying marital status, and (2) around 140,000 married women. Table A in the appendix presents means, standard deviations, and definitions for the variables used in our analysis for the two samples for the U.S. as a whole. Descriptive statistics by U.S. region are provided in Table B.

\section{B) Empirical Methodology}

We first specify a parsimonious model of women's LFP that excludes any potentially endogenous regressors:

$$
\operatorname{Pr}\left(L F P_{i}=1\right)=\Phi\left(\beta_{1} S R_{i r}+\beta_{2} \text { trend }+\beta_{3} A_{i}+\beta_{4} N L I_{i}+\beta_{5} R_{i}+\beta_{6} R_{i} * S R+\beta_{7} R_{i} * \text { trend }\right)
$$

where $\Phi$ stands for the standard normal cumulative distribution, LFP equals 1 if women are in the labor force, $S R$ is the sex ratio for women in a particular birth cohort and region, $A$ indicates the particular age group to which the female respondent belongs to, NLI represents women's non-labor income, $R$ stands for region dummies, and trend is a time trend. Interactions between the sex ratios and the region dummies recognize regional differences in changes in cohort size due principally to regional differences in fertility, inter-region as well as international migration.

\footnotetext{
${ }^{13}$ Table 1 indicates that this decline covered all regions: the LFP rate of married women declined in every U.S. region during those ten years.
} 
Interactions between the time trend and the region dummies address difficult to capture trends in work and family attitudes, as well as differences in the adoption timing of specific time-saving technologies across regions (see Greenwood and Guner 2004) -all factors that could impact the LFP of women at different rates depending on the region where they live.

However, the model specified in equation (1) ignores the role played by other factors known to affect women's LFP discussed earlier, including their educational attainment, average wages earned by similar women, and the number of young children they may have. Therefore, we also estimate a model that includes women’s educational attainment $\left(E^{f}\right)$, the average market wage for women in their age/education group residing in a specific region in a particular year $\left(\bar{w}_{A E R T}^{f}\right)$, and the number of young children $(F)$, which results in our second specification:

$$
\begin{aligned}
& \operatorname{Pr}\left(L F P_{i}=1\right)=\Phi\left(\beta_{1} S R_{i r}+\beta_{2} \text { trend }+\beta_{3} A_{i}+\beta_{4} N L I_{i}+\beta_{5} R_{i}+\beta_{6} R_{i} * S R+\beta_{7} R_{i} * \text { trend }+\right. \\
& \left.+\beta_{8} E_{i}^{f}+\beta_{9} \bar{w}_{A E R T}^{f}+\beta_{10} F_{i}\right)
\end{aligned}
$$

Yet, if we want to further assess whether sex ratios have a differential effect on married women's LFP rates depending on their educational attainment, we need to interact the sex ratio $(S R)$ with women's educational attainment $\left(E^{f}\right)$. It follows from our earlier discussion that the coefficient of this interaction term is expected to be negative. We also include interactions between women's educational attainment and region of residence to account for regional differences in educational levels and policies. Finally, a three-way interaction term of sex ratios, women's educational attainment, and region dummies allows us to test whether there are regional differences in sex ratio effects by educational attainment. Hence, our third model specification is given by:

$$
\begin{aligned}
& \operatorname{Pr}\left(L F P_{i}=1\right)=\Phi\left(\beta_{1} S R_{i r}+\beta_{2} \text { trend }+\beta_{3} A_{i}+\beta_{4} N L I_{i}+\beta_{5} R_{i}+\beta_{6} R_{i} * S R+\beta_{7} R_{i} * \text { trend }+\right. \\
& \left.+\beta_{8} E_{i}^{f}+\beta_{9} \bar{w}_{A E R T}^{f}+\beta_{10} F+\beta_{11} E_{i}^{f} * S R+\beta_{12} E_{i}^{f} * R+\beta_{13} R_{i} * E_{i}^{f} * S R\right)
\end{aligned}
$$


All three models are estimated separately for: (a) women of any marital status and (b) for married women to gauge the robustness of the sex ratio effect on women's LFP depending on their marital status.

\section{Results}

Estimations of models 1 through 3 for the U.S. as a whole are displayed in Tables 2A through 2C. The corresponding results by U.S. region are shown in Tables 3A through 3C. ${ }^{14}$ Each table presents results for women of any marital status and for married women. Models 1 and 2 involve a test of our main prediction: that sex ratios and women’s LFP are inversely related. In accordance with our prediction, we find a negative association between sex ratio and women's LFP in all estimations of models 1 and 2, whether we just consider married women or whether we look at women of any marital status. For example, according to parsimonious model 1 (Table 2A), an increase in the sex ratio from 1.00 to 1.10 is associated with a decrease in the LFP of married women of 2.15 percentage points. The corresponding decrease in the LFP of women of any marital status is 3 percentage points.

The regressions presented in Tables 2B and 3B test model 2. They show that, despite weakening, sex ratio effects on women's LFP remain robust to the inclusion of women's wages, education, and presence of young children in the analysis. For instance, the effect on LFP of an increase in sex ratio of .10 is comparable to that of an increase in education of a little more than 2 years. The lower sex ratio effects in Table 2B (after controlling for education, income and the presence of small children in the household) than in Table 2A (which lacks such controls) is suggestive of both Easterlin's explanation and the marriage market explanation of sex ratio effects applying to the parsimonious model estimates of Table 2A.

\footnotetext{
${ }^{14}$ We have also estimated models 2 and 3 excluding fertility to gauge the robustness of the sex ratio effects to the exclusion of this variable. Results were very similar to the ones we report and are available from the authors upon request.
} 
In the regressions in Tables 2A and 2B, sex ratio effects are the result of both regional and cohort-level variation in sex ratios. The regional models in Table 3A estimate the parsimonious model for each region separately. Within each region, the sex ratio effect originates from differences in cohort size due to fluctuations in the number of births around women's birth year. Sex ratio effects on women's LFP are smaller in the Midwest than in any of the other major three regions of the U.S., while they are strongest in the Northeast and the West. For example, in the West, an increase in sex ratio from 1.00 to 1.10 is associated with a decrease in the LFP of married women of up to 6.5 percentage points. One can only speculate as to why there is a greater effect of sex ratio on women's LFP in these regions. Could there be more variation in women's bargaining power in marriage (an implication of Step 1 in both the D\&S and collective models) in certain regions? Perhaps such bargaining power is related to sex ratios, with the Midwest having a substantially higher mean sex ratio over the period under study. For instance, the average sex ratio for the period under analysis was 1.03 in the Midwest compared to 0.96 in the Northeast and West, and 0.95 in the South. This means that marriage market conditions in the Midwest are more favorable to women, which could possibly stem from selective gender migration.

We also predicted that the inverse association between the sex ratio and female LFP is less likely to hold for more educated women than for women with less education, i.e. the interaction term between the sex ratio and women's years of schooling in equation (3) is expected to be positive. Model 3, containing an interaction term between the sex ratio and female education and the corresponding regional dummies, is estimated for the U.S. as a whole (Table 2C) and for each major region (Table 3C). The results from Table 2C indicate that the interaction between education and sex ratio has a negative sign among married women, whereas 
the simple effect of sex ratio is positive in the case of the reference region (the Midwest). The net effect of sex ratio in the Midwest and the Northeast is negative (obtained after adding the negative marginal effect -0.08 to the positive marginal effect 0.13 ), while the interaction between education and sex ratio has a positive sign. Among women of any marital status, the interaction between education and sex ratio is not significant, except in the West, where it takes a positive sign.

In light of the regional differences pointed out earlier, we also display the results by region. It is also apparent from the results in Table 3C that sex ratio effects vary by education in opposite ways in the Midwest relative to the Northeast and West of the U.S. Our prediction was that material quasi-wages matter more in marriages involving less educated women, among whom traditional gender roles are likely to play a more important role than among marriages involving more educated women. This prediction seems to apply in the West and the Northeast, but not in the Midwest. The possibility exists that economic conditions in the Midwest induced more educated married women in this region to step into the labor force at a higher rate than their counterparts in the Northeast and West of the U.S.

Next, we investigate whether the sign on the interaction terms between female education and the sex ratio possibly originated from a positive correlation between male and female education. Specifically, for married women, we estimate a fourth model similar to model (3) that, in addition to the sex ratio interacted with the wife's education, includes the husband's education and interactions between the sex ratio and the husband's education. This model was first estimated for the U.S. as a whole. Results are displayed in Table 4. According to our estimates in Table 4, adding husbands' educational attainment and the corresponding interaction 
terms does not increase the explanatory power of our model. The new terms are statistically not different from zero.

However, because regional differences could mask cohort-level sex ratio effects, similar regressions are also estimated by region in Table 5. We find evidence of a larger negative sex ratio effect on the LFP of women married to more educated men in the Northeast and the South. This result confirms the importance of incorporating men's earning power when calculating how sex ratios affect marriage conditions, as argued by Lichter et al. (1995).

\section{Discussion and Conclusions}

Using individual CPS data for selected years spanning 1965 to 2005, we test the prediction of a negative association between sex ratios and women's LFP for married women as well as for all women regardless of their marital status. For the U.S. as a whole, variation in the sex ratio -the ratio of men two years older to women two years younger regardless of marital status- is obtained from regional differences and cohort differences. A negative association between sex ratios and women's LFP could be the result of differences in labor market opportunities across regions which, in turn, could lead to migrating patterns that end up changing sex ratios in the aforementioned direction. Therefore, we also carry the analysis by U.S. regions so that sex ratio effects only reflect cohort-level effects.

After accounting for a time trend and other relevant factors, we find that women born during a baby-boom and, therefore, facing a low sex ratio when they enter dating and marriage markets twenty years later, had significantly higher LFP than women born in a baby-bust or during times of constant population growth. Vice-versa, women who were born during a babybust and, therefore, experiencing a high sex ratio in marriage markets, had significantly lower LFP than women born in a baby-boom or during times of constant population growth. These 
results, which hold for all women, regardless of their marital status, as well as for the U.S. as a whole and for most U.S. regions, are based on the assumption that the difference in average age at marriage between men and women stays equal to two years over the entire period studied -a reasonable assumption given the actual evolution of that age difference.

Our results help explain why in recent years we have observed some drops in women’s LFP, such as a decrease of 3.5 percentage points between 1995 and 2005 in the LFP rates for married women ages 30 to 34 (see Table 1). During those years, the women who entered these age groups were women of the Moon and Roe generations characterized by high sex ratios. In contrast, when women from cohorts characterized by low sex ratios entered this age group, we observe rapid increases in their LFP. For instance, married women of the Post World War II generation, born in the years 1946-1950, experienced an increase in LFP of 13.5 percentage points when they entered the same age category between 1970 and 1975.

We also predicted that the negative association between sex ratios and women's LFP would be less valid for educated women than for women with low education. Two regions offer evidence for this prediction: the West and the Northeast. In those regions, sex ratio effects on women’s LFP are stronger for women who are less educated. In the Midwest, we consistently get the opposite result, i.e. sex ratio effects on women's LFP are stronger for more educated women. Additionally, the analysis by women's marital status reveals that our prediction of a smaller sex ratio effect on women's LFP among more educated women -a prediction that makes sense within the context of an economic analysis of bargaining in marriage, is corroborated for married women.

To the extent that it applies to women with partners, our basic finding of an inverse association between sex ratio and women's LFP is consistent with both D\&S and collective 
models of decision-making in marriage or cohabitation. According to the collective models, higher sex ratios imply that women will obtain a more advantageous sharing rule when they and their partners (or partners to be) bargain over the distribution of resources that were pooled together. According to the Grossbard's D\&S model, higher sex ratios imply that marriage markets have established more advantageous quasi-wages for female household production workers. Our second finding -a positive association between women's LFP and the interaction between female education and sex ratio is interpreted in terms of less educated women being more interested in working in remunerated household production. In the Midwest, we find a negative association between women's LFP and the interaction between female education and sex ratio. This result could be indicative of educated women living in the Midwest encountering a greater opportunity cost for not working.

In future work, it would be of interest to use alternative measures of sex ratio, including measures that only take singles into account -either calibrated to every single-year birth cohort or considering a range of possible age differences as in Goldman et al. (1984). Likewise, it would be helpful to gain a better understanding of how sex ratios affect other dimensions of labor supply, such as the labor supply of men, and the attachment of men and women to the labor force in an international context. 


\section{References}

Angrist, J. \& Evans, W. N. (2002). How do sex ratios affect marriage and labor markets?

Evidence from America's second generation. Quarterly Journal of Economics 117, 997-1038.

Becker, G. S. (1973) A theory of marriage: part 1. Journal of Political Economy 81, 813-846. . (1981), A Treatise on the Family. Cambridge: Harvard University Press.

Chiappori, P.-A. (1988). Rational household labor supply. Econometrica 56, 63-90.

Chiappori, P.-A. (1992). Collective labor supply and welfare. Journal of Political Economy 100, 437-67.

Chiappori, P.-A. (1997). Introducing household production in collective models of labor supply. Journal of Political Economy 105, 191-209.

Chiappori, P.-A., Fortin, B. \& Lacroix,G. (2002). Marriage market, divorce legislation, and household labor supply. Journal of Political Economy, 110, 37-71.

Deville, J.-C. (1977). Activite feminine et fecondite. Economie et Statistique, 93, 51-58.

Donohue, J. J. III \& Levitt, S.D. (2001). The impact of legalized abortion on crime. Quarterly Journal of Economics 66, 379-420.

Easterlin, R. A. (1980). Birth and Fortune: The Effects of Generation Size on Personal Welfare. New York: Basic Books.

Ekert, O. (1983). Activite feminine, prestations familiales et redistribution. Population, 38, 503526.

Fukuda, K. (2006). A cohort analysis of female labor force participation rates in the U.S. and Japan. Review of Economics of the Household 4, 379-393.

Goldin, C. (1990). Understanding the Gender Gap. Oxford: Oxford University Press.

Goldman, N., Westoff, C. \& Hammerslough,C. (1984) Demography of the marriage market in the United States. Population Index, 50, 5-25.

Greenwood, J. \& Guner, N. (2004). "Marriage and divorce since World War II: analyzing the role of technological progress on the formation of households”, NBER Working Papers 10772, National Bureau of Economic Research, Inc.

Grossbard-Shechtman, A. (1984) A Theory of Allocation of Time in Markets for Labour and Marriage.” Economic Journal 94, 863-82.

Grossbard-Shechtman, S.A. (1993). On the economics of marriage. Boulder (Co.): Westview 
Press.

Grossbard-Shechtman, S. \& Granger, C.W.J. (1998). Women’s jobs and marriage: baby-boom or baby-bust. Population 53, 731-52 (In French).

Grossbard-Shechtman, S. \& Neideffer, M. (1997). Women’s hours of work and marriage market imbalances," in Economics of the Family and Family Policies, edited by Persson, I.\& Jonung,C. London: Routledge.

Grossbard-Shechtman S. \& Neuman, S. (1988). Labor supply and marital choice. Journal of Political Economy, 96, 1294-1302.

Guttentag, M. \& Secord, P. F. (1983). Too Many Women: The Sex Ratio Question. Beverly Hills: Sage Publications, 1983.

Heer, D. M. \& Grossbard-Shechtman, A. (1981). The impact of the female marriage squeeze and the contraceptive revolution on sex roles and the women's Liberation Movement in the United States, 1960 to 1975.” Journal of Marriage and the Family, 43, 49-65.

Hersch, J. (2003) Marriage, household production, and earnings. In Shoshana GrossbardShechtman, (ed.). Marriage and the Economy. Cambridge and New York: Cambridge University Press.

Huet, M. (1977). Emploi et Activite entre 1968 et 1975. Economie et Statistique, 94, 59-76.

Lehrer, E. L. \& Nerlove, M. (1986). Female labor force behavior and fertility in the United States. Annual Review of Sociology, 12, 181-204.

Leibowitz, A. \& Klerman, J.A. (1995). Explaining changes in married mothers' employment over time.” Demography, 32, 365-70.

Lichter, D. T., Anderson, R.N.\& Hayward, M.D. (1995). Marriage markets and marital choice. Journal of Family Issues, 16, 412-431.

Lundberg, S. \& Pollak, R.A. (1993). Separate sphere bargaining and the marriage market. Journal of Political Economy, 101, 988-1010.

Mincer, J. (1962). Labor force participation of married women: a study of labor supply. In Aspects of Labor Economics, edited by H. Gregg Lewis. Princeton, N.J.: Princeton University Press.

. (1985). Intercountry comparisons of labor force trends and of related developments: an overview. Journal of Labor Economics, 3, S1-S32.

Oreffice, S. (2007). Legalization of abortion, intra-household bargaining power, and labor 
supply. Review of Economics of the Household , 5. (forthcoming)

Pencavel, J. (1998). “The market work behavior and wages of women: 1975-94.” Journal of Human Resources, 33, 772-804.

Rapoport, B., Sofer, C. \& Solaz, A. "Household production in a collective model: some new results,” Ms., Université Paris 1.

Rosen, S. (1992). Mincering labor economics. Journal of Economic Perspectives, 6, 157-170.

Shapiro, D. \& Shaw, L.B. (1983). Growth in the labor force attachment of married women: accounting for changes in the 1970s. Southern Economic Journal, 50, 461-473.

Smith, J. P. \& Ward, M.P. (1984). Women's wages and work in the Twentieth Century. Rand Publications. 
Table 1

Generations of Women, Sex Ratios, and Changes in Married Women's Labor Force Participation for Four Regions in the United States

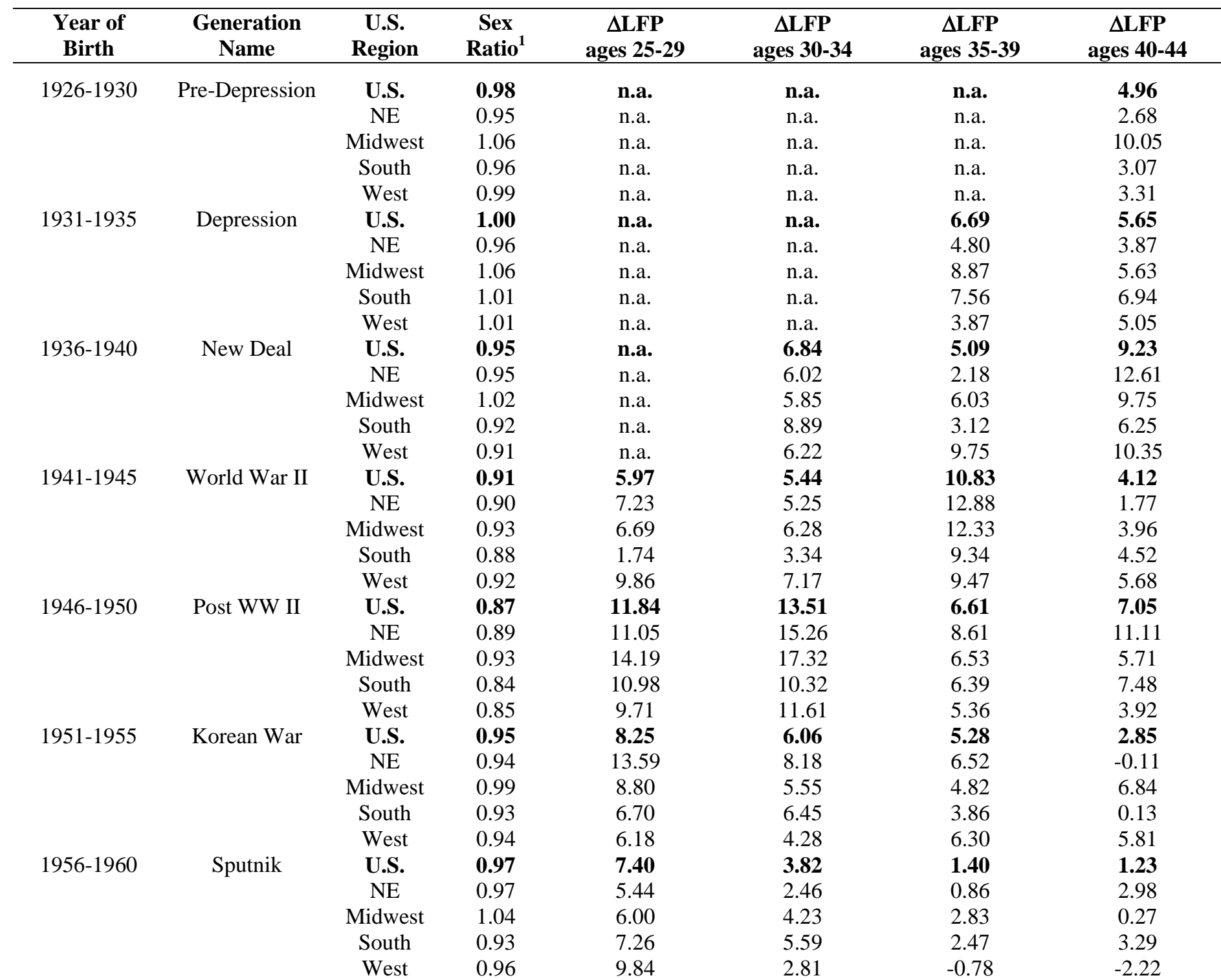


Table 1 - Continued

\begin{tabular}{|c|c|c|c|c|c|c|c|}
\hline $\begin{array}{c}\text { Year of } \\
\text { Birth }\end{array}$ & $\begin{array}{c}\text { Generation } \\
\text { Name }\end{array}$ & $\begin{array}{c}\text { U.S. } \\
\text { Region }\end{array}$ & $\begin{array}{c}\text { Sex } \\
\text { Ratio } \\
\end{array}$ & $\begin{array}{c}\Delta \mathrm{LFP} \\
\text { ages } 25-29\end{array}$ & $\begin{array}{c}\Delta \mathrm{LFP} \\
\text { ages } 30-34\end{array}$ & $\begin{array}{c}\Delta \mathrm{LFP} \\
\text { ages } 35-39\end{array}$ & $\begin{array}{c}\Delta \mathrm{LFP} \\
\text { ages } 40-44\end{array}$ \\
\hline \multirow[t]{5}{*}{ 1961-1965 } & Kennedy & U.S. & 1.03 & 3.49 & 3.62 & -1.84 & n.a. \\
\hline & & $\mathrm{NE}$ & 1.01 & 2.54 & 4.54 & -0.77 & n.a. \\
\hline & & Midwest & 1.09 & 6.18 & 5.03 & -2.67 & n.a. \\
\hline & & South & 1.01 & 6.90 & 2.98 & -0.58 & n.a. \\
\hline & & West & 1.01 & -2.31 & 2.19 & -2.97 & n.a. \\
\hline \multirow[t]{5}{*}{ 1966-1970 } & Moon & U.S. & 1.06 & -0.14 & -2.14 & n.a. & n.a. \\
\hline & & $\mathrm{NE}$ & 1.05 & 2.59 & -0.80 & n.a. & n.a. \\
\hline & & Midwest & 1.16 & 4.28 & -2.00 & n.a. & n.a. \\
\hline & & South & 1.03 & -5.06 & -1.22 & n.a. & n.a. \\
\hline & & West & 1.02 & -0.38 & -4.45 & п.а. & n.a. \\
\hline \multirow[t]{5}{*}{ 1971-1975 } & Roe & U.S. & 1.07 & 0.76 & n.a. & n.a. & n.a. \\
\hline & & $\mathrm{NE}$ & 1.05 & 1.62 & n.a. & n.a. & n.a. \\
\hline & & Midwest & 1.11 & -0.11 & n.a. & n.a. & n.a. \\
\hline & & South & 1.06 & 4.06 & n.a. & n.a. & n.a. \\
\hline & & West & 1.06 & -1.24 & n.a. & n.a. & n.a. \\
\hline \multirow[t]{5}{*}{$1976-1980$} & First Echo & U.S. & 1.01 & n.a. & n.a. & n.a. & n.a. \\
\hline & & $\mathrm{NE}$ & 1.01 & n.a. & n.a. & n.a. & n.a. \\
\hline & & Midwest & 1.08 & n.a. & n.a. & n.a. & n.a. \\
\hline & & South & 0.97 & n.a. & n.a. & n.a. & n.a. \\
\hline & & West & 0.98 & n.a. & n.а. & n.a. & n.a. \\
\hline
\end{tabular}

Notes: ${ }^{1}$ Ratio of men age 22 to 26 to women age 20 to 24 or men age 27 to 31 to women age 25 to 29 calculated based on Census data from 1940 to 2000. The age group depends on the Census year. Sex ratios for last generation were calculated based on the 2000 Census using younger age groups. ${ }^{2}$ Calculated from CPS years 1965-2005. 
Table 2A: Probit Regression Estimates of Women's Labor Force Participation - Model (1)

\begin{tabular}{|c|c|c|c|c|c|c|}
\hline \multirow{2}{*}{ Variables } & \multicolumn{3}{|c|}{ Married Women } & \multicolumn{3}{|c|}{ All Women } \\
\hline & Coeff. & S.E. & M.E. & Coeff. & S.E. & M.E. \\
\hline SR & $-0.572 * * *$ & 0.118 & -0.215 & $-0.873 * * *$ & 0.104 & -0.301 \\
\hline Age 25-29 & $-0.197 * * *$ & 0.010 & -0.075 & $-0.113^{* * *}$ & 0.009 & -0.040 \\
\hline Age $30-34$ & $-0.184 * * *$ & 0.010 & -0.070 & $-0.120 * * *$ & 0.009 & -0.043 \\
\hline Age 35-39 & $-0.069 * * *$ & 0.010 & -0.026 & $-0.053 * * *$ & 0.009 & -0.019 \\
\hline NLI & $-5.14 \mathrm{E}-6 * * *$ & $1.76 \mathrm{E}-7$ & $-1.93 E-6$ & $-7.53 \mathrm{E}-6 * * *$ & $1.56 \mathrm{E}-7$ & $-2.7 E-6$ \\
\hline NE & $0.968 * * *$ & 0.211 & 0.310 & $0.331^{*}$ & 0.108 & 0.111 \\
\hline South & $0.406^{* *}$ & 0.153 & 0.147 & 0.120 & 0.113 & 0.042 \\
\hline West & $1.207 * * *$ & 0.170 & 0.373 & $0.651 * * *$ & 0.148 & 0.207 \\
\hline Time Trend & $0.033 * * *$ & 0.001 & 0.012 & $0.030 * * *$ & 0.001 & 0.011 \\
\hline NE*Time Trend & -0.002 & 0.001 & -0.001 & $-0.002^{* *}$ & 0.001 & -0.001 \\
\hline South*Time Trend & $-0.001 * * *$ & 0.001 & -0.004 & $-0.007 * * *$ & 0.001 & -0.003 \\
\hline West*Time Trend & $-0.011^{* * *}$ & 0.001 & -0.004 & $-0.010 * * *$ & 0.001 & -0.004 \\
\hline NE*SR & $-1.102 * * *$ & 0.228 & -0.414 & $-0.463^{* *}$ & 0.195 & -0.164 \\
\hline South*SR & $-0.295^{*}$ & 0.163 & -0.111 & -0.074 & 0.143 & -0.026 \\
\hline West*SR & $-1.159 * * *$ & 0.183 & -0.435 & $-0.608 * * *$ & 0.160 & -0.216 \\
\hline Number of observations & & 140592 & & & 197991 & \\
\hline Wald Chi-square & & 8677.45 & & & 10784.86 & \\
\hline Prob $>$ Chi-square & & 0.000 & & & 0.000 & \\
\hline
\end{tabular}

Notes: S.E. stands for 'standard error' and M.E. for 'marginal effect.' * significant at p > .10; ** significant at $\mathrm{p}>.05 ; * * *$ significant at $\mathrm{p}>.01$. All regressions include a constant term. Age 40-44 and Midwest are used as reference categories. 
Table 2B: Probit Regression Estimates of Women's Labor Force Participation - Model (2)

\begin{tabular}{|c|c|c|c|c|c|c|}
\hline \multirow{2}{*}{ Variables } & \multicolumn{3}{|c|}{ Married Women } & \multicolumn{3}{|c|}{ All Women } \\
\hline & Coeff. & S.E. & M.E. & Coeff. & S.E. & M.E. \\
\hline SR & $-0.219 *$ & 0.120 & -0.082 & $-0.558 * * *$ & 0.108 & -0.195 \\
\hline Age 25-29 & 0.015 & 0.012 & 0.005 & $0.064 * * *$ & 0.010 & 0.022 \\
\hline Age $30-34$ & $0.045^{* * *}$ & 0.011 & -0.017 & 0.002 & 0.010 & 0.001 \\
\hline Age 35-39 & $-0.019 *$ & 0.011 & -0.007 & -0.009 & 0.009 & -0.003 \\
\hline NLI & $-8.0 \mathrm{E}-6^{* * *}$ & $2.0 \mathrm{E}-7$ & $-2.9 \mathrm{E}-06$ & $-9.95 \mathrm{E}-6 * * *$ & $1.8 \mathrm{E}-7$ & $-3.5 E-6$ \\
\hline $\mathrm{NE}$ & $0.692^{* * *}$ & 0.216 & 0.232 & 0.173 & 0.185 & 0.059 \\
\hline South & 0.212 & 0.157 & 0.077 & -0.095 & 0.139 & -0.033 \\
\hline West & $0.577^{* * *}$ & 0.178 & 0.199 & -0.017 & 0.157 & -0.006 \\
\hline Time Trend & $0.016 * *$ & 0.001 & 0.006 & $0.012^{* * *}$ & 0.001 & 0.004 \\
\hline NE*Time Trend & $-0.003 * * *$ & 0.001 & -0.001 & $-0.003 * * *$ & 0.001 & -0.001 \\
\hline South*Time Trend & $-0.010 * * *$ & 0.001 & -0.004 & $-0.009 * * *$ & 0.001 & -0.003 \\
\hline West*Time Trend & $-0.005^{* * *}$ & 0.001 & -0.002 & $-0.004 * * *$ & 0.001 & -0.001 \\
\hline $\mathrm{NE}^{*} \mathrm{SR}$ & $-0.801 * * *$ & 0.233 & -0.299 & -0.293 & 0.200 & -0.102 \\
\hline South*SR & -0.037 & 0.168 & -0.014 & 0.224 & 0.148 & 0.078 \\
\hline West*SR & $-0.583^{* * *}$ & 0.190 & -0.217 & 0.004 & 0.168 & 0.001 \\
\hline Young Children & $-0.425 * * *$ & 0.007 & -0.158 & $-0.463^{* * *}$ & 0.006 & -0.161 \\
\hline Education & $0.093 * * *$ & 0.001 & 0.035 & $0.106 * * *$ & 0.001 & 0.037 \\
\hline Average Wages & $7.2 \mathrm{E}-5^{* * *}$ & $5.6 \mathrm{E}-6$ & 2.7E-05 & 7.1E-5*** & 4.7E-6 & $2.5 \mathrm{E}-5$ \\
\hline Number of observations & & 140592 & & & 197189 & \\
\hline Wald Chi-square & & 15007.38 & & & 22117.23 & \\
\hline Prob $>$ Chi-square & & 0.000 & & & 0.000 & \\
\hline
\end{tabular}

Notes: S.E. stands for 'standard error' and M.E. for 'marginal effect.' * significant at $\mathrm{p}>$.10; ${ }^{* *}$ significant at $\mathrm{p}$ $>.05$; *** significant at $\mathrm{p}>.01$. All regressions include a constant term. Age 40-44 and Midwest are used as reference categories. 
Table 2C: Probit Regression Estimates of Women's Labor Force Participation - Model (3)

\begin{tabular}{|c|c|c|c|c|c|c|}
\hline \multirow{2}{*}{ Variables } & \multicolumn{3}{|c|}{ Married Women } & \multicolumn{3}{|c|}{ All Women } \\
\hline & Coeff. & S.E. & M.E. & Coeff. & S.E. & M.E. \\
\hline SR & $2.623 * * *$ & 0.560 & 0.978 & -0.836 & 0.513 & -0.292 \\
\hline Age 25-29 & $0.017^{* * *}$ & 0.012 & 0.006 & $0.064 * * *$ & 0.010 & 0.022 \\
\hline Age 30-34 & -0.043 & 0.011 & -0.016 & 0.002 & 0.010 & -0.001 \\
\hline Age 35-39 & -0.020 & 0.011 & -0.007 & -0.010 & 0.009 & -0.003 \\
\hline NLI & $-7.9 \mathrm{E}-6 * * *$ & $2.0 \mathrm{E}-7$ & $-3.0 \mathrm{E}-6$ & $-10.0 \mathrm{E}-6^{* * *}$ & $1.8 \mathrm{E}-7$ & $-3.5 E-6$ \\
\hline $\mathrm{NE}$ & $4.784 * * *$ & 1.006 & 0.749 & 1.103 & 0.832 & 0.308 \\
\hline South & $3.050 * * *$ & 0.761 & 0.699 & -0.731 & 0.657 & 0.267 \\
\hline West & $5.162 * * *$ & 0.801 & 0.802 & $1.273^{*}$ & 0.699 & 0.346 \\
\hline Time Trend & $0.016^{* * *}$ & 0.001 & 0.006 & $0.012^{* * *}$ & 0.001 & 0.004 \\
\hline NE*Time Trend & $-0.002 * *$ & 0.001 & -0.001 & $-0.003^{* * *}$ & 0.001 & -0.001 \\
\hline South*Time Trend & $-0.010^{* * *}$ & 0.001 & -0.004 & $-0.009 * * *$ & 0.001 & -0.003 \\
\hline West*Time Trend & $-0.005^{* * *}$ & 0.001 & -0.002 & $-0.003^{* * *}$ & 0.001 & -0.001 \\
\hline NE*SR & $-4.510^{* * *}$ & 1.028 & -1.714 & -1.261 & 0.849 & -0.440 \\
\hline South*SR & $-2.850 * * *$ & 0.775 & -1.029 & 0.857 & 0.662 & 0.230 \\
\hline West*SR & $-5.170 * * *$ & 0.815 & -1.928 & $-1.288^{*}$ & 0.704 & -0.450 \\
\hline Young Children & $-0.424^{* * *}$ & 0.007 & -0.159 & $-0.463 * * *$ & 0.006 & -0.162 \\
\hline Education & $0.323 * * *$ & 0.046 & 0.121 & $0.086^{* *}$ & 0.040 & 0.030 \\
\hline Average Wages & $7.2 \mathrm{E}-5^{* * *}$ & $5.6 \mathrm{E}-6$ & $2.7 \mathrm{E}-5$ & $7.1 \mathrm{E}-5^{* * *}$ & 4.7E-6 & $2.5 \mathrm{E}-5$ \\
\hline Education*SR & $-0.211^{* *}$ & 0.045 & -0.082 & 0.022 & 0.039 & 0.008 \\
\hline NE*Education & -0.315 & 0.074 & -0.118 & $-0.071 * * *$ & 0.062 & -0.024 \\
\hline South* Education & $-0.220 * * *$ & 0.059 & -0.082 & 0.050 & 0.502 & 0.018 \\
\hline West*Education & $-0.356 * *$ & 0.061 & -0.133 & $-0.102^{*}$ & 0.053 & -0.036 \\
\hline NE*Education*SR & 0.290 & 0.076 & 0.108 & 0.074 & 0.063 & 0.026 \\
\hline South*Education*SR & 0.211 & 0.051 & 0.079 & -0.050 & 0.051 & -0.017 \\
\hline West*Education*SR & $0.357 * *$ & 0.061 & 0.133 & $0.102 *$ & 0.053 & 0.035 \\
\hline Number of observations & & 140952 & & & 197189 & \\
\hline Wald Chi-square & & 15137.15 & & & 2102.14 & \\
\hline Prob $>$ Chi-square & & 0.000 & & & 0.000 & \\
\hline
\end{tabular}

Notes: S.E. stands for 'standard error' and M.E. for 'marginal effect.' * Significant at $\mathrm{p}>.10$; ** significant at $\mathrm{p}>.05$; *** significant at $\mathrm{p}>.01$. All regressions include a constant term. Age 40-44 and Midwest are used as reference categories. 
Table 3A: Regression Estimates of Women's Labor Force Participation by Region: Model (1)

\begin{tabular}{|c|c|c|c|c|c|c|c|c|c|c|c|c|}
\hline \multirow{2}{*}{ Variables } & \multicolumn{3}{|c|}{ Married: Northeast } & \multicolumn{3}{|c|}{ All: Northeast } & \multicolumn{3}{|c|}{ Married: Midwest } & \multicolumn{3}{|c|}{ All: Midwest } \\
\hline & Coeff. & S.E. & M.E. & Coeff. & S.E. & M.E. & Coeff. & S.E. & M.E. & Coeff. & S.E. & M.E. \\
\hline SR & $-1.536 * * *$ & 0.158 & -0.562 & $-1.601 * * *$ & 0.193 & -0.614 & $-0.794^{* * *}$ & 0.097 & -0.278 & $-.860 * * *$ & .105 & -0.300 \\
\hline Age $25-29$ & $-0.044 * * *$ & 0.019 & -0.016 & $-0.186 * * *$ & 0.023 & -0.072 & $-0.125 * * *$ & 0.018 & -0.045 & $-.131 * * *$ & .018 & -0.047 \\
\hline Age $30-34$ & $-0.131 * * *$ & 0.018 & -0.049 & $-0.205^{* * *}$ & 0.021 & -0.080 & $-0.139 * * *$ & 0.018 & -0.049 & $-.143 * * *$ & .018 & -0.051 \\
\hline Age 35-39 & $-0.064 * * *$ & 0.018 & -0.023 & $-0.093 * * *$ & 0.021 & -0.036 & $-0.039 * *$ & 0.018 & -0.014 & $-.040 * * *$ & .018 & -0.014 \\
\hline NLI & $-5.1 \mathrm{E}-6 * * *$ & 2.7E-7 & $-1.9 \mathrm{E}-6$ & $-5.5 \mathrm{E}-6 * * *$ & $3.8 \mathrm{E}-7$ & $-2.1 \mathrm{E}-6$ & $-7.6 \mathrm{E}-6 * * *$ & $2.9 \mathrm{E}-7$ & $-2.6 \mathrm{E}-6$ & $-8.5 e-06^{\star \star \star}$ & $3.36 e-07$ & $-2.9 \mathrm{E}-6$ \\
\hline Time Trend & $0.027 * * *$ & 0.001 & 0.010 & $0.031 * * *$ & 0.001 & 0.012 & $0.029 * * *$ & 0.001 & 0.010 & 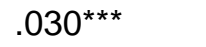 & .0006154 & 0.010 \\
\hline Wald Chi-square & & 2602.4 & & & 2363. & & & 3769.4 & & & 3528.79 & \\
\hline Prob $>$ Chi-square & & 0.000 & & & 0.00 & & & 0.000 & & & 0.000 & \\
\hline \multirow{2}{*}{ Variables } & \multicolumn{3}{|c|}{ Married: South } & \multicolumn{3}{|c|}{ All: South } & \multicolumn{3}{|c|}{ Married: West } & \multicolumn{3}{|c|}{ All: West } \\
\hline & Coeff. & S.E. & M.E. & Coeff. & S.E. & M.E. & Coeff. & S.E. & M.E. & Coeff. & S.E. & M.E. \\
\hline SR & $-0.904 * * *$ & 0.091 & -0.320 & $-0.843 * * *$ & 0.108 & -0.318 & $-1.219 * * *$ & 0.114 & -0.438 & $-1.557 * * *$ & 0.134 & -0.593 \\
\hline Age $25-29$ & $-0.089 * * *$ & 0.016 & -0.032 & $-0.168 * * *$ & 0.019 & -0.064 & $-0.169 * * *$ & 0.018 & -0.062 & $-0.210^{* * *}$ & 0.021 & -0.081 \\
\hline Age 30-34 & $-0.070 * * *$ & 0.016 & -0.025 & $-0.110 * * *$ & 0.018 & -0.042 & $-0.137 * * *$ & 0.018 & -0.050 & $-0.180 * * *$ & 0.020 & -0.070 \\
\hline NLI & $-7.3 \mathrm{E}-6^{* * *}$ & 2.6E-7 & $-2.6 \mathrm{E}-6$ & $-5.0 \mathrm{E}-6^{* * *}$ & $3.1 \mathrm{E}-7$ & $-1.9 \mathrm{E}-6$ & $-6.4 \mathrm{E}-6^{* * *}$ & 3.3E-7 & $-2.3 E-6$ & $-3.2 \mathrm{E}-6^{* * *}$ & 3.6E-7 & $-1.2 \mathrm{E}-6$ \\
\hline Time Trend & $0.022 * * *$ & 0.001 & 0.008 & $0.024 * * *$ & 0.001 & 0.009 & $0.019 * * *$ & 0.001 & -0.438 & $0.021^{* * *}$ & 0.001 & 0.008 \\
\hline Observations & \multicolumn{3}{|c|}{73387} & \multicolumn{3}{|c|}{48395} & \multicolumn{3}{|c|}{57056} & \multicolumn{3}{|c|}{37650} \\
\hline Wald Chi-square & \multicolumn{3}{|c|}{3048.15} & \multicolumn{3}{|c|}{2363.26} & \multicolumn{3}{|c|}{1654.14} & \multicolumn{3}{|c|}{1348.52} \\
\hline Prob $>$ Chi-square & \multicolumn{3}{|c|}{0.000} & \multicolumn{3}{|c|}{0.000} & \multicolumn{3}{|c|}{0.000} & \multicolumn{3}{|c|}{0.000} \\
\hline
\end{tabular}

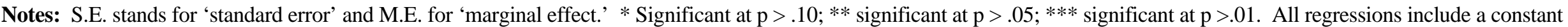
term. Age 40-44 is used as reference categories. 
Table 3B: Regression Estimates of Women's Labor Force Participation by Region: Model (2)

\begin{tabular}{|c|c|c|c|c|c|c|c|c|c|c|c|c|}
\hline \multirow{2}{*}{ Variables } & \multicolumn{3}{|c|}{ Married: Northeast } & \multicolumn{3}{|c|}{ All: Northeast } & \multicolumn{3}{|c|}{ Married: Midwest } & \multicolumn{3}{|c|}{ All: Midwest } \\
\hline & Coeff. & S.E. & M.E. & Coeff. & S.E. & M.E. & Coeff. & S.E. & M.E. & Coeff. & S.E. & M.E. \\
\hline SR & $-0.609 * * *$ & 0.170 & -0.220 & $-0.875^{* * *}$ & 0.205 & -0.334 & $-0.402 * * *$ & 0.103 & -0.138 & -0.058 & 0.118 & -0.021 \\
\hline Age 25-29 & $0.086^{* * *}$ & 0.020 & 0.031 & $-4.4 \mathrm{E}-4$ & 0.024 & 0.000 & $0.036^{*}$ & 0.020 & 0.012 & $-0.055^{* *}$ & 0.024 & -0.020 \\
\hline Age $30-34$ & -0.011 & 0.019 & -0.004 & $-0.072 * * *$ & 0.023 & -0.027 & -0.022 & 0.020 & -0.008 & $-0.153 * * *$ & 0.023 & -0.057 \\
\hline Age 35-39 & -0.017 & 0.019 & -0.006 & $-0.041^{*}$ & 0.022 & -0.016 & -0.013 & 0.019 & -0.004 & $-0.035^{*}$ & 0.021 & -0.013 \\
\hline NLI & $-7.7 \mathrm{E}-6 * * *$ & $3.1 \mathrm{E}-7$ & $-2.8 \mathrm{E}-6$ & $-7.6 \mathrm{E}-6 * * *$ & 4.3E-7 & $-2.9 \mathrm{E}-6$ & $-9.7 \mathrm{E}-6 * * *$ & 3.3E-7 & $-3.3 E-6$ & $-9.1 \mathrm{E}-6 * * *$ & $4.2 \mathrm{E}-7$ & $-3.4 \mathrm{E}-6$ \\
\hline Time Trend & $0.012 * * *$ & 0.001 & 0.004 & $0.024 * * *$ & 0.002 & 0.009 & $0.020^{* * *}$ & 0.001 & 0.007 & $0.026 * * *$ & 0.002 & 0.010 \\
\hline Young Children & $-0.550 * * *$ & 0.012 & -0.198 & $-0.497 * * *$ & 0.014 & -0.190 & $-0.484 * * *$ & 0.011 & -0.166 & $-0.433 * * *$ & 0.013 & -0.160 \\
\hline Education & $0.100 * * *$ & 0.002 & 0.036 & $0.078 * * *$ & 0.003 & 0.030 & $0.107 * * *$ & 0.003 & 0.037 & $0.105^{* * *}$ & 0.003 & 0.039 \\
\hline Average Wages & $6.1 \mathrm{E}-5 * * *$ & 5.7E-6 & $2.2 \mathrm{E}-5$ & $2.8 \mathrm{E}-5 * * *$ & $8.4 \mathrm{E}-6$ & $1.1 \mathrm{E}-5$ & $3.4 \mathrm{E}-5 * * *$ & $6.2 \mathrm{E}-6$ & $1.2 \mathrm{E}-5$ & $2.1 \mathrm{E}-5^{* * *}$ & 8.4E-6 & 7.6E-6 \\
\hline Observations & & 53551 & & & 334 & & & 5772 & & & 3986 & \\
\hline Wald Chi-square & & 6089.5 & & & 3829 & & & 6810. & & & 5054 & \\
\hline Prob > Chi-square & & 0.000 & & & 0.00 & & & 0.00 & & & 0.00 & \\
\hline \multirow{2}{*}{ Variables } & \multicolumn{3}{|c|}{ Married: South } & \multicolumn{3}{|c|}{ All: South } & \multicolumn{3}{|c|}{ Married: West } & \multicolumn{3}{|c|}{ All: West } \\
\hline & Coeff. & S.E. & M.E. & Coeff. & S.E. & M.E. & Coeff. & S.E. & M.E. & Coeff. & S.E. & M.E. \\
\hline SR & $-0.361 * * *$ & 0.102 & -0.126 & $-0.484 * * *$ & 0.120 & -0.181 & $-0.376^{* * *}$ & 0.129 & -0.133 & $-0.580 * * *$ & 0.155 & -0.219 \\
\hline Age $25-29$ & 0.012 & 0.018 & 0.004 & $-0.066^{* * *}$ & 0.021 & -0.025 & $0.087 * * *$ & 0.022 & 0.030 & $0.076 * * *$ & 0.027 & 0.029 \\
\hline Age $30-34$ & -0.018 & 0.017 & -0.006 & $-0.064 * * *$ & 0.020 & -0.024 & 0.019 & 0.020 & 0.007 & -0.011 & 0.023 & -0.004 \\
\hline Age 35-39 & -0.016 & 0.017 & -0.006 & $-0.037 * *$ & 0.019 & -0.014 & -0.016 & 0.019 & -0.006 & -0.026 & 0.022 & -0.010 \\
\hline NLI & $-1.1 \mathrm{E}-5^{* * *}$ & $3.1 \mathrm{E}-7$ & $-3.8 E-6$ & $-8.4 \mathrm{E}-6 * * *$ & $3.8 \mathrm{E}-7$ & $-3.2 \mathrm{E}-6$ & $-8.7 \mathrm{E}-6 * * *$ & 4.1E-7 & $-3.1 E-6$ & $-6.4 \mathrm{E}-6 * * *$ & $4.8 \mathrm{E}-7$ & $-2.4 \mathrm{E}-6$ \\
\hline Time Trend & $0.012^{* * *}$ & 0.001 & 0.004 & $0.021 * * *$ & 0.002 & 0.008 & $0.010^{* * *}$ & 0.001 & 0.003 & $0.011 * * *$ & 0.002 & 0.004 \\
\hline Young Children & $-0.442^{* * *}$ & 0.010 & -0.154 & $-0.400 * * *$ & 0.012 & -0.150 & $-0.483^{* * *}$ & 0.011 & -0.171 & $-0.443^{* * *}$ & 0.012 & -0.168 \\
\hline Education & $0.109 * * *$ & 0.002 & 0.038 & $0.098 * * *$ & 0.003 & 0.037 & $0.099 * * *$ & 0.002 & 0.035 & $0.096 * * *$ & 0.003 & 0.036 \\
\hline Average Wages & $3.2 \mathrm{E}-5 * * *$ & $6.1 \mathrm{E}-6$ & $1.1 \mathrm{E}-5$ & 8.0E-8 & $8.0 \mathrm{E}-6$ & 3.0E-8 & $7.0 \mathrm{E}-5 * * *$ & 7.7E-6 & $2.5 \mathrm{E}-5$ & $7.8 \mathrm{E}-5 * * *$ & $9.9 \mathrm{E}-6$ & 2.9E-5 \\
\hline Observations & \multicolumn{3}{|c|}{73073} & \multicolumn{3}{|c|}{48245} & \multicolumn{3}{|c|}{56740} & \multicolumn{3}{|c|}{37489} \\
\hline Wald Chi-square & \multicolumn{3}{|c|}{7250.65} & \multicolumn{3}{|c|}{4567.44} & \multicolumn{3}{|c|}{5350.18} & \multicolumn{3}{|c|}{6305.48} \\
\hline Prob $>$ Chi-square & \multicolumn{3}{|c|}{0.000} & \multicolumn{3}{|c|}{0.000} & \multicolumn{3}{|c|}{0.000} & \multicolumn{3}{|c|}{0.000} \\
\hline
\end{tabular}

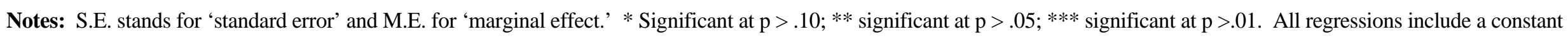
term. Age 40-44 is used as reference categories. 
Table 3C: Regression Estimates of Women's Labor Force Participation by Region: Model (3)

\begin{tabular}{|c|c|c|c|c|c|c|c|c|c|c|c|c|}
\hline \multirow{2}{*}{ Variables } & \multicolumn{3}{|c|}{ Married: Northeast } & \multicolumn{3}{|c|}{ All: Northeast } & \multicolumn{3}{|c|}{ Married: Midwest } & \multicolumn{3}{|c|}{ All: Midwest } \\
\hline & Coeff. & S.E. & M.E. & Coeff. & S.E. & M.E. & Coeff. & S.E. & M.E. & Coeff. & S.E. & M.E. \\
\hline SR & $-1.243^{* *}$ & 0.614 & -0.448 & -0.628 & 0.798 & -0.240 & -0.140 & 0.469 & -0.048 & $2.907 * * *$ & 0.567 & 1.077 \\
\hline Age 25-29 & $0.086 * * *$ & 0.020 & 0.031 & 0.000 & 0.024 & 0.000 & $0.037 *$ & 0.020 & 0.012 & $-0.045^{*}$ & 0.024 & -0.017 \\
\hline Age 30-34 & -0.011 & 0.019 & -0.004 & $-0.071 * * *$ & 0.023 & -0.027 & -0.021 & 0.020 & -0.007 & $-0.140 * * *$ & 0.023 & -0.053 \\
\hline Age 35-39 & -0.018 & 0.019 & -0.006 & $-0.041^{*}$ & 0.022 & -0.016 & -0.012 & 0.019 & -0.004 & -0.030 & 0.022 & -0.011 \\
\hline NLI & $-7.8 \mathrm{E}-6 * * *$ & $3.1 \mathrm{E}-7$ & $-2.8 E-6$ & $-7.6 \mathrm{E}-6 * * *$ & 4.3E-7 & $-2.9 \mathrm{E}-6$ & $-9.7 \mathrm{E}-6 * * *$ & 3.3E-7 & $-3.3 E-6$ & $-9.0 \mathrm{E}-6 * * *$ & 4.2E-7 & $-3.3 E-6$ \\
\hline Time Trend & $0.012 * * *$ & 0.001 & 0.004 & $0.024 * * *$ & 0.002 & 0.009 & $0.020 * * *$ & 0.001 & 0.007 & $0.026 * * *$ & 0.002 & 0.009 \\
\hline Young Children & $-0.550 * * *$ & 0.012 & -0.198 & $-0.497 * * *$ & 0.014 & -0.190 & $-0.484 * * *$ & 0.011 & -0.166 & $-0.432 * * *$ & 0.013 & -0.160 \\
\hline Education & 0.053 & 0.043 & 0.019 & 0.096* & 0.056 & 0.037 & $0.128 * * *$ & 0.037 & 0.044 & $0.341 * * *$ & 0.044 & 0.127 \\
\hline Average Wages & $6.1 \mathrm{E}-5^{* * *}$ & $5.7 \mathrm{E}-6$ & $2.2 \mathrm{E}-5$ & $2.8 \mathrm{E}-5^{* * *}$ & $8.4 \mathrm{E}-6$ & $1.1 \mathrm{E}-5$ & $3.4 \mathrm{E}-5 * * *$ & 6.3E-6 & $1.2 \mathrm{E}-5$ & $2.5 \mathrm{E}-5 * * *$ & 8.5E-6 & $9.2 \mathrm{E}-6$ \\
\hline Education*SR & 0.049 & 0.045 & 0.018 & -0.019 & 0.058 & -0.007 & -0.020 & 0.036 & -0.007 & $-0.231 * * *$ & 0.043 & -0.086 \\
\hline Observations & \multirow{3}{*}{\multicolumn{3}{|c|}{$\begin{array}{c}53551 \\
6080.56 \\
0.000\end{array}$}} & \multirow{3}{*}{\multicolumn{3}{|c|}{$\begin{array}{c}33449 \\
3833.92 \\
0.000\end{array}$}} & \multirow{3}{*}{\multicolumn{3}{|c|}{$\begin{array}{c}57722 \\
6825.03 \\
0.000\end{array}$}} & \multirow{3}{*}{\multicolumn{3}{|c|}{$\begin{array}{c}39868 \\
5161.73 \\
0.000\end{array}$}} \\
\hline Wald Chi-square & & & & & & & & & & & & \\
\hline Prob $>$ Chi-square & & & & & & & & & & & & \\
\hline \multirow{2}{*}{ Variables } & \multicolumn{3}{|c|}{ Married: South } & \multicolumn{3}{|c|}{ All: South } & \multicolumn{3}{|c|}{ Married: West } & \multicolumn{3}{|c|}{ All: West } \\
\hline & Coeff. & S.E. & M.E. & Coeff. & S.E. & M.E. & Coeff. & S.E. & M.E. & Coeff. & S.E. & M.E. \\
\hline SR & -0.091 & 0.384 & -0.032 & -0.502 & 0.471 & -0.188 & $-1.295^{* * *}$ & 0.455 & -0.458 & $-1.740 * * *$ & 0.539 & -0.659 \\
\hline Age $25-29$ & 0.013 & 0.018 & 0.005 & $-0.066 * * *$ & 0.021 & -0.025 & $0.087 * * *$ & 0.022 & 0.030 & $0.077 * * *$ & 0.027 & 0.029 \\
\hline Age 30-34 & -0.017 & 0.017 & -0.006 & $-0.064 * * *$ & 0.020 & -0.024 & 0.018 & 0.020 & 0.006 & -0.012 & 0.023 & -0.005 \\
\hline Age 35-39 & -0.016 & 0.017 & -0.005 & $-0.037 * *$ & 0.019 & -0.014 & -0.016 & 0.019 & -0.006 & -0.026 & 0.022 & -0.010 \\
\hline NLI & $-1.1 \mathrm{E}-5^{* * *}$ & $3.1 \mathrm{E}-7$ & $-3.8 E-6$ & $-8.4 \mathrm{E}-6 * * *$ & $3.8 \mathrm{E}-7$ & $-3.2 E-6$ & $-8.7 \mathrm{E}-6^{* * *}$ & 4.1E-7 & $-3.1 E-6$ & $-6.5 \mathrm{E}-6^{* * *}$ & $4.8 \mathrm{E}-7$ & $-2.4 \mathrm{E}-6$ \\
\hline Time Trend & $0.012 * * *$ & 0.001 & 0.004 & $0.021 * * *$ & 0.002 & 0.008 & $0.010^{* * *}$ & 0.001 & 0.003 & $0.011^{* * *}$ & 0.002 & 0.004 \\
\hline Young Children & $-0.442 * * *$ & 0.010 & -0.154 & $-0.400 * * *$ & 0.012 & -0.150 & $-0.482 * * *$ & 0.011 & -0.171 & $-0.443^{* * *}$ & 0.012 & -0.168 \\
\hline Education & $0.129 * * *$ & 0.028 & 0.045 & $0.097 * * *$ & 0.034 & 0.036 & 0.029 & 0.033 & 0.010 & 0.009 & 0.039 & 0.003 \\
\hline Average Wages & $3.2 \mathrm{E}-5 * * *$ & $6.2 \mathrm{E}-6$ & $1.1 \mathrm{E}-5$ & 5.6E-8 & 8.1E-6 & $2.1 \mathrm{E}-8$ & $7.0 \mathrm{E}-5 * * *$ & 7.7E-6 & $2.5 \mathrm{E}-5$ & $7.7 \mathrm{E}-5 * * *$ & $9.9 \mathrm{E}-6$ & 2.9E-5 \\
\hline Education*SR & -0.022 & 0.030 & -0.008 & 0.001 & 0.036 & 0.001 & $0.073^{* *}$ & 0.034 & 0.026 & $0.091^{* *}$ & 0.040 & 0.034 \\
\hline Observations & \multicolumn{3}{|c|}{73073} & \multicolumn{3}{|c|}{48245} & \multicolumn{3}{|c|}{56740} & \multicolumn{3}{|c|}{37489} \\
\hline Wald Chi-square & \multicolumn{3}{|c|}{7268.07} & \multicolumn{3}{|c|}{4568.79} & \multicolumn{3}{|c|}{5332.11} & \multicolumn{3}{|c|}{3591.66} \\
\hline Prob $>$ Chi-square & \multicolumn{3}{|c|}{0.000} & \multicolumn{3}{|c|}{0.000} & \multicolumn{3}{|c|}{0.000} & \multicolumn{3}{|c|}{0.000} \\
\hline
\end{tabular}

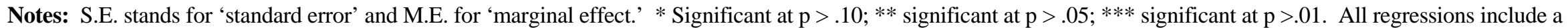
constant term. Age 40-44 is used as reference categories. 
Table 4

Regression Estimates of Married Women's Labor Force Participation

\begin{tabular}{|c|c|c|c|}
\hline \multirow{2}{*}{ Variables } & \multicolumn{3}{|c|}{ Model (3) with Husband Information } \\
\hline & Coeff. & S.E. & M.E. \\
\hline SR & $2.891 * * *$ & 0.639 & 1.078 \\
\hline Age 25-29 & $0.025 * *$ & 0.012 & 0.009 \\
\hline Age 30-34 & $-0.035^{* * *}$ & 0.011 & -0.013 \\
\hline Age 35-39 & -0.014 & 0.011 & -0.005 \\
\hline NLI & $-7.4 \mathrm{E}-06 * * *$ & 2.1E-07 & $-2.8 \mathrm{E}-06$ \\
\hline $\mathrm{NE}$ & $4.115^{* * *}$ & 1.08 & 0.691 \\
\hline South & $2.806 * * *$ & 0.815 & 0.661 \\
\hline West & $5.481 * * *$ & 0.866 & 0.821 \\
\hline Time Trend & $0.016^{* * *}$ & 0.001 & 0.006 \\
\hline NE*Time Trend & -0.001 & 0.001 & -0.001 \\
\hline South*Time Trend & $-0.010 * * *$ & 0.001 & -0.004 \\
\hline West*Time Trend & $-0.005^{* * *}$ & 0.001 & -0.002 \\
\hline $\mathrm{NE}^{*} \mathrm{SR}$ & $-3.839 * * *$ & 1.106 & -1.431 \\
\hline South*SR & $-2.492 * * *$ & 0.822 & -0.929 \\
\hline West*SR & $-5.521 * * *$ & 0.874 & -2.058 \\
\hline Young Children & $-0.425^{* * *}$ & 0.007 & -0.159 \\
\hline Education & $0.338 * * *$ & 0.057 & 0.126 \\
\hline Average Wages & $7.4 \mathrm{E}-05^{* * *}$ & 5.6E-06 & $2.7-05$ \\
\hline Education*SR & $-0.211 * * *$ & 0.056 & -0.082 \\
\hline NE*Education & $-0.380 * * *$ & 0.094 & -0.142 \\
\hline South* Education & $-0.271^{* * *}$ & 0.074 & -0.101 \\
\hline West*Education & $-0.335^{* * *}$ & 0.077 & -0.125 \\
\hline NE*Education*SR & $0.365^{* * *}$ & 0.962 & 0.136 \\
\hline South*Education*SR & $0.265^{* * *}$ & 0.075 & 0.099 \\
\hline West*Education*SR & $0.327 * * *$ & 0.077 & 0.122 \\
\hline Husband's Education & 0.004 & 0.049 & 0.002 \\
\hline Husband's Education*SR & -0.025 & 0.041 & -0.009 \\
\hline NE*Husband's Education & 0.116 & 0.049 & 0.043 \\
\hline South* Husband's Education & 0.071 & 0.084 & 0.026 \\
\hline West*Husband’s Education & -0.047 & 0.064 & -0.018 \\
\hline NE*Husband's Education*SR & -0.133 & 0.068 & -0.050 \\
\hline South*Husband's Education*SR & -0.076 & 0.087 & -0.028 \\
\hline West*Husband’s Education*SR & 0.059 & 0.074 & 0.022 \\
\hline Number of observations & & 140133 & \\
\hline Wald Chi-square & & 15325.43 & \\
\hline Prob $>$ Chi-square & & 0.000 & \\
\hline
\end{tabular}

Notes: S.E. stands for 'standard error' and M.E. for 'marginal effect.' * Significant at p > .10; ** significant at $\mathrm{p}>.05 ; * * *$ significant at $\mathrm{p}>.01$. All regressions include a constant term. Age 40-44 and Midwest are used as reference categories. 
Table 5

Regression Estimates of Married Women's Labor Force Participation by Region: Model (3) with Husband Information

\begin{tabular}{|c|c|c|c|c|c|c|c|c|c|c|c|c|}
\hline \multirow{2}{*}{ Variables } & \multicolumn{3}{|c|}{ Northeast } & \multicolumn{3}{|c|}{ Midwest } & \multicolumn{3}{|c|}{ South } & \multicolumn{3}{|c|}{ West } \\
\hline & Coeff. & S.E. & M.E. & Coeff. & S.E. & M.E. & Coeff. & S.E. & M.E. & Coeff. & S.E. & M.E. \\
\hline SR & 0.442 & 0.858 & 0.155 & $3.232 * * *$ & 0.606 & 1.181 & -0.076 & 0.491 & -0.021 & $-1.735 * * *$ & 0.577 & -0.652 \\
\hline Age 25-29 & 0.010 & 0.024 & 0.004 & $-0.039 *$ & 0.024 & -0.014 & $-0.060 * * *$ & 0.021 & -0.023 & $0.080 * * *$ & 0.027 & 0.030 \\
\hline Age 30-34 & $-0.060 * * *$ & 0.023 & -0.023 & $-0.134 * * *$ & 0.023 & -0.050 & $-0.060 * * *$ & 0.020 & -0.023 & -0.008 & 0.023 & -0.003 \\
\hline Age 35-39 & $-0.037 *$ & 0.022 & -0.014 & -0.028 & 0.022 & -0.010 & $-0.035 *$ & 0.019 & -0.013 & -0.025 & 0.022 & -0.009 \\
\hline NLI & $-6.8 \mathrm{E}-6^{* * *}$ & $4.4 \mathrm{E}-7$ & $-2.6 \mathrm{E}-6$ & $-8.7 \mathrm{E}-6 * * *$ & 4.3E-7 & $-3.2 E-6$ & $-8.2 E-6 * * *$ & $3.9 \mathrm{E}-7$ & $-3.1 E-6$ & $-6.2 \mathrm{E}-6 * * *$ & $4.8 \mathrm{E}-7$ & $-2.4 \mathrm{E}-6$ \\
\hline Time Trend & $0.025 * * *$ & 0.002 & 0.009 & $0.026 * * *$ & 0.002 & 0.010 & $0.021 * * *$ & 0.002 & 0.008 & $0.011^{* * *}$ & 0.002 & 0.004 \\
\hline Young Children & $-0.500 * * *$ & 0.014 & -0.191 & $-0.433 * * *$ & 0.013 & -0.161 & $-0.400 * * *$ & 0.012 & -0.150 & $-0.447 * * *$ & 0.012 & -0.169 \\
\hline Education & 0.034 & 0.072 & 0.016 & $0.333 * * *$ & 0.055 & 0.126 & 0.050 & 0.044 & 0.017 & 0.027 & 0.049 & 0.011 \\
\hline Average Wages & $3.0 \mathrm{E}-5 * * *$ & $8.4 \mathrm{E}-6$ & $1.1 \mathrm{E}-5$ & $2.6 \mathrm{E}-5^{* * *}$ & 8.5E-6 & $9.4 \mathrm{E}-6$ & 7.9E-7 & 8.1E-6 & $3.2 \mathrm{E}-7$ & $7.8 \mathrm{E}-5 * * *$ & $9.9 \mathrm{E}-6$ & $3.0 \mathrm{E}-5$ \\
\hline Education*SR & 0.066 & 0.075 & 0.023 & $-0.213 * * *$ & 0.053 & -0.081 & 0.058 & 0.047 & 0.023 & 0.080 & 0.052 & 0.029 \\
\hline Husband's Education & $0.134 * *$ & 0.065 & 0.047 & 0.031 & 0.047 & 0.008 & $0.077 * *$ & 0.038 & 0.031 & -0.020 & 0.044 & -0.008 \\
\hline Husband's Education*SR & $-0.171 * *$ & 0.068 & -0.061 & -0.046 & 0.047 & -0.013 & $-0.092 * *$ & 0.040 & -0.037 & 0.009 & 0.046 & 0.004 \\
\hline Observations & \multicolumn{3}{|c|}{33341} & \multicolumn{3}{|c|}{39792} & \multicolumn{3}{|c|}{48104} & \multicolumn{3}{|c|}{37318} \\
\hline Wald Chi-square & \multicolumn{3}{|c|}{3910.05} & \multirow{2}{*}{\multicolumn{3}{|c|}{5175.73}} & \multicolumn{3}{|c|}{4582.85} & \multicolumn{3}{|c|}{3633.43} \\
\hline Prob $>$ Chi-square & \multicolumn{3}{|c|}{0.000} & & \multicolumn{2}{|l|}{0.000} & \multicolumn{3}{|c|}{0.000} & \multicolumn{3}{|c|}{0.000} \\
\hline
\end{tabular}

Notes: S.E. stands for 'standard error' and M.E. for 'marginal effect.' * Significant at $\mathrm{p}>.10$; ** significant at $\mathrm{p}>.05$; *** significant at $\mathrm{p}>.01$. All regressions include a constant term. Age 40-44 is used as reference categories. 


\section{APPENDIX TABLES \\ Table A}

Variable Definitions, Means and Standard Deviations

\begin{tabular}{|c|c|c|c|}
\hline Variables & Definitions & Mean & S.D. \\
\hline \multicolumn{4}{|c|}{ All Women } \\
\hline LFP & Dummy equal to 1 if in the labor force & 0.68 & 0.47 \\
\hline $\mathrm{SR}^{1}$ & Sex ratio & 0.98 & 0.07 \\
\hline Age 2529 & Age group dummy & 0.21 & 0.41 \\
\hline Age 3034 & Age group dummy & 0.21 & 0.41 \\
\hline Age 3539 & Age group dummy & 0.20 & 0.40 \\
\hline Age 4044 & Age group dummy & 0.19 & 0.39 \\
\hline Young Children & Number of children three years old and younger & 0.27 & 0.54 \\
\hline Education & Years of schooling & 12.84 & 2.70 \\
\hline Average Wages & Average female wages for that age/education/region/year cell & 7714.44 & 2584.04 \\
\hline NLI & Household non-labor income (including public assistance) & 20409.33 & -20801.74 \\
\hline $\mathrm{NE}$ & Region dummy & 0.22 & 0.42 \\
\hline Midwest & Region dummy & 0.24 & 0.43 \\
\hline South & Region dummy & 0.30 & 0.46 \\
\hline West & Region dummy & 0.24 & 0.42 \\
\hline Trend & Time trend & 21.91 & 11.91 \\
\hline \multicolumn{4}{|c|}{ Married Women } \\
\hline LFP & Dummy equal to 1 if in the labor force & 0.63 & 0.48 \\
\hline SR & Sex ratio & 0.97 & 0.07 \\
\hline Age 2529 & Age group dummy & 0.20 & 0.40 \\
\hline Age 3034 & Age group dummy & 0.23 & 0.42 \\
\hline Age 3539 & Age group dummy & 0.23 & 0.42 \\
\hline Age 4044 & Age group dummy & 0.22 & 0.42 \\
\hline Young Children & Number of children three years old and younger & 0.33 & 0.58 \\
\hline Education & Years of schooling & 12.82 & 2.68 \\
\hline Husband's Education & Years of schooling & 12.93 & 3.08 \\
\hline Average Wages & Average female wages for that age/education/region/year cell & 7781.38 & 2634.59 \\
\hline NLI & Household non-labor income (including public assistance) & 25749.14 & 20302.99 \\
\hline $\mathrm{NE}$ & Region dummy & 0.21 & 0.41 \\
\hline Midwest & Region dummy & 0.25 & 0.43 \\
\hline South & Region dummy & 0.30 & 0.46 \\
\hline West & Region dummy & 0.24 & 0.43 \\
\hline Trend $^{2}$ & Time trend & 21.16 & 12.31 \\
\hline
\end{tabular}

Sources: March CPS 1965-2000. ${ }^{1}$ U.S. Bureau of the Census. See the notes at the bottom of Table $1 .{ }^{2}$ The time trend takes the following values: 0 for 1965, 5 for 1970, 10 for 1975, and so on until 40 for 2005. 
Table B

Variable Definitions, Means and Standard Deviations by Region

\begin{tabular}{|c|c|c|c|c|c|c|c|c|}
\hline \multirow{3}{*}{ Variables } & \multicolumn{4}{|c|}{ Northeast } & \multicolumn{4}{|c|}{ Midwest } \\
\hline & \multicolumn{2}{|c|}{ Married } & \multicolumn{2}{|c|}{ All } & \multicolumn{2}{|c|}{ Married } & \multicolumn{2}{|c|}{ All } \\
\hline & Mean & S.D. & Mean & S.D. & Mean & S.D. & Mean & S.D. \\
\hline LFP & 0.66 & 0.47 & 0.60 & 0.49 & 0.69 & 0.46 & 0.63 & 0.48 \\
\hline $\mathrm{SR}^{1}$ & 0.96 & 0.05 & 0.96 & 0.05 & 1.03 & 0.07 & 1.03 & 0.07 \\
\hline Age 2529 & 0.20 & 0.40 & 0.19 & 0.39 & 0.21 & 0.41 & 0.20 & 0.40 \\
\hline Age 3034 & 0.21 & 0.41 & 0.24 & 0.43 & 0.21 & 0.41 & 0.24 & 0.43 \\
\hline Age 3539 & 0.21 & 0.40 & 0.24 & 0.43 & 0.20 & 0.40 & 0.23 & 0.42 \\
\hline Age 4044 & 0.20 & 0.40 & 0.24 & 0.43 & 0.19 & 0.39 & 0.22 & 0.41 \\
\hline Young Children & 0.25 & 0.52 & 0.33 & 0.58 & 0.28 & 0.55 & 0.33 & 0.59 \\
\hline Education & 13.01 & 2.71 & 13.03 & 2.66 & 12.95 & 2.42 & 12.91 & 2.39 \\
\hline Husband's Education & - & - & 13.16 & 2.99 & - & - & 13.04 & 2.79 \\
\hline Average Wages & 7965.09 & 2716.98 & 8039.81 & 2805.39 & 7643.42 & 2749.32 & 7663.47 & 2842.56 \\
\hline NLI & 21668.23 & 21330.90 & 27109.43 & 20229.05 & 21369.21 & 20641.06 & 26258.41 & 19793.04 \\
\hline $\mathrm{NE}$ & 1.00 & 0.00 & 1.00 & 0.00 & 0.00 & 0.00 & 0.00 & 0.00 \\
\hline Midwest & 0.00 & 0.00 & 0.00 & 0.00 & 1.00 & 0.00 & 1.00 & 0.00 \\
\hline South & 0.00 & 0.00 & 0.00 & 0.00 & 0.00 & 0.00 & 0.00 & 0.00 \\
\hline West & 0.00 & 0.00 & 0.00 & 0.00 & 0.00 & 0.00 & 0.00 & 0.00 \\
\hline \multirow[t]{2}{*}{ Trend } & 21.44 & 11.93 & 20.63 & 12.44 & 21.21 & 12.18 & 20.38 & 12.55 \\
\hline & \multicolumn{4}{|c|}{ South } & \multicolumn{4}{|c|}{ West } \\
\hline \multirow[t]{2}{*}{ Variables } & \multicolumn{2}{|c|}{ Married } & \multicolumn{2}{|c|}{ All } & \multicolumn{2}{|c|}{ Married } & \multicolumn{2}{|c|}{ All } \\
\hline & Mean & S.D. & Mean & S.D. & Mean & S.D. & Mean & S.D. \\
\hline LFP & 0.68 & 0.47 & 0.63 & 0.48 & 0.67 & 0.47 & 0.62 & 0.49 \\
\hline $\mathrm{SR}^{1}$ & 0.95 & 0.07 & 0.95 & 0.06 & 0.96 & 0.06 & 0.96 & 0.06 \\
\hline Age 2529 & 0.21 & 0.41 & 0.20 & 0.40 & 0.22 & 0.41 & 0.22 & 0.41 \\
\hline Age 3034 & 0.21 & 0.41 & 0.23 & 0.42 & 0.22 & 0.41 & 0.23 & 0.42 \\
\hline Age 3539 & 0.20 & 0.40 & 0.22 & 0.42 & 0.20 & 0.40 & 0.23 & 0.42 \\
\hline Age 4044 & 0.19 & 0.39 & 0.21 & 0.41 & 0.18 & 0.39 & 0.21 & 0.40 \\
\hline Young Children & 0.26 & 0.53 & 0.30 & 0.56 & 0.30 & 0.57 & 0.37 & 0.61 \\
\hline Education & 12.63 & 2.79 & 12.58 & 2.77 & 12.85 & 2.82 & 12.81 & 2.86 \\
\hline Husband's Education & - & - & 12.58 & 3.27 & - & - & 13.06 & 3.15 \\
\hline Average Wages & 7679.10 & 2679.83 & 7703.38 & 2715.46 & 7595.84 & 2095.45 & 7756.92 & 2090.30 \\
\hline NLI & 18851.96 & 20167.25 & 24008.70 & 20116.01 & 20252.88 & 21127.08 & 25976.47 & 20820.87 \\
\hline $\mathrm{NE}$ & 0.00 & 0.00 & 0.00 & 0.00 & 0.00 & 0.00 & 0.00 & 0.00 \\
\hline Midwest & 0.00 & 0.00 & 0.00 & 0.00 & 0.00 & 0.00 & 0.00 & 0.00 \\
\hline South & 1.00 & 0.00 & 1.00 & 0.00 & 0.00 & 0.00 & 0.00 & 0.00 \\
\hline West & 0.00 & 0.00 & 0.00 & 0.00 & 1.00 & 0.00 & 1.00 & 0.00 \\
\hline Trend $^{2}$ & 21.92 & 11.96 & 21.01 & 12.28 & 23.03 & 11.48 & 22.67 & 11.85 \\
\hline
\end{tabular}

Sources: March CPS 1965-2000. ${ }^{1}$ U.S. Bureau of the Census. See the notes at the bottom of Table $1 .{ }^{2}$ The time trend takes the following values: 0 for 1965, 5 for 1970, 10 for 1975, and so on until 40 for 2005. 